\title{
THE INNOVATION PROCESS IN LOCAL DEVELOPMENT - THE MATERIAL, INSTITUTIONAL, AND INTELLECTUAL INFRASTRUCTURE SHAPING AND SHAPED BY INNOVATION
}

\author{
Magdalena GORZELANY-DZIADKOWIEC (D) ${ }^{1}$, Julia GORZELANY (D) 2*, \\ Gintaras STAUSKIS ${ }^{\mathbb{D}}{ }^{3}$, Józef HERNIK ${ }^{\mathbb{D} 2}$, Kristof VAN ASSCHE ${ }^{\mathbb{1} 4}$, \\ Tomasz NOSZCZYK (D)2 \\ ${ }^{1}$ Department of Management Strategy and Organization Development, \\ Cracow University of Economics, Kraków, Poland \\ ${ }^{2}$ Department of Land Management and Landscape Architecture, \\ University of Agriculture in Krakow, Kraków, Poland \\ ${ }^{3}$ Department of Urban Design, Vilnius Gediminas Technical University, Vilnius, Lithuania \\ ${ }^{4}$ Department of Planning, Governance and Development, Faculty of Extension and Faculty of Science, \\ University of Alberta, Edmonton, Canada
}

Received 28 November 2018; accepted 09 June 2019

\begin{abstract}
The purpose of the article is to define the material, institutional, and intellectual infrastructure of a region and identify the innovative processes that determine its creation. Our main research hypothesis is that the processes that influence the creation of a region's infrastructure determine a region's competitiveness as well. To verify these premises, we conducted a study among the residents and employees of a municipality. The research employed deductive and inductive methods and a qualitative analysis was performed. Pearson's linear correlation coefficient and factor analysis (inference based on the modal and median values) were used in the study. The research verified the hypothesis that innovative processes influence the creation of a region's infrastructure and that innovative processes in the studied region exhibit low dynamics, which is caused by financial and psychosocial barriers. The important role of social leaders in municipalities was identified as well, above all as regards building civic society and social activity. The added value of the article is threefold: the developed model of infrastructure construction in the material, institutional, and intellectual dimensions of a region; recommendations for the investigated municipality; and a structured questionnaire that, together with the model, can be used for research in municipalities.
\end{abstract}

Keywords: regional development, regional competitiveness, material infrastructure, institutional infrastructure, intellectual infrastructure, entrepreneurship behavior, municipal management, model of infrastructure construction.

JEL Classification: R50, O31.

${ }^{\star}$ Corresponding author. E-mail: j.gorzelany@ur.krakow.pl

This is an Open Access article distributed under the terms of the Creative Commons Attribution License (http://creativecommons. $\mathrm{org} / \mathrm{licenses} / \mathrm{by} / 4.0 /$ ), which permits unrestricted use, distribution, and reproduction in any medium, provided the original author and source are credited. 


\section{Introduction}

Sustainable regional development is a problem for many researchers because rather than being uniquely defined, it is determined by various factors (Romao \& Neuts, 2017). Determinants of regional development have been grouped in the literature according to different concepts. The first group includes factors determining a region's ability to respond to external changes (e.g., through the use of EU funds). The authors focus on regional planning from development control to the presentation of regional policy procedures (Hausner, Kudłacz, \& Szlachta, 1998). The second group includes determinants distinguished by such factors as economic, social, spatial, ecological, local, technical, and technological. These distinguishing factors, directly and indirectly, stimulate regional development (Rowe, 2019). Public administration is also listed by some as a determinant of regional development (Kotnik \& Kovac, 2018; Sunina \& Rivza, 2016).

Municipal managers often seem to think that the presence of large industrial plants or large area networks in a municipality or the pursuit of aggressive environmental services improves the region's competitiveness (Baula, Galaziuk, \& Zelinska, 2017). Yet, it should be emphasized that a municipality's material (natural resources, technological resources, property), institutional (institutions, investments, undertaken and completed activities), and intellectual (intellectual capital, social capital) infrastructure has a significant impact on the quality of life, providing its inhabitants with clean air, the qualities of nature, and the support of native enterprises. With these resources (which are specific and relatively rare), regions may compete with other regions that have sought development in various industries (Raszkowski \& Bartniczak, 2018). It is, therefore, important for managers to focus on the design and development of the material, institutional, and intellectual infrastructure that their residents desire (Dos Santos, 2007). The material infrastructure of a region is formed by the region's natural (environmental), material (property), and technological resources (tools, means of work). The institutional infrastructure includes activities undertaken by the parents and institutions together with investment skills and operational programs. The third infrastructure is the intellectual infrastructure. Elements in this group are difficult to identify and measure because they are built on intellectual and social capital. A significant source of these types of infrastructure is the innovation process that is more than just innovation: it requires gaining both strategic and competitive advantage over other regions (Baula et al., 2017) and contributing to a change in an organization's behavior and values - that is, its organizational culture (Sanchez-Carreira, Penate-Valentin, \& Varela-Vazquez, 2017). Innovation processes are a valuable source of competitive advantage, but they require entrepreneurial behavior (Davids \& Frenken, 2018). Entrepreneurship is one of the determinants of the intellectual and institutional infrastructure in an organization (Agovino, Aldieri, Garofalo, \& Vinci, 2017).

This is why the primary objective of the paper is to analyze the influence of innovation processes on the shaping of the local material, institutional, and intellectual infrastructure. The study focuses on the Myslenice Municipality (Malopolska Voivodeship, Poland) in order to demonstrate how these types of infrastructure are shaped and affected by innovation processes. The following specific objectives were devised to reach the primary objective:

- To identify innovation processes in the creation of material, institutional, and intellectual infrastructure. 
- To determine the dynamics of such innovation processes.

- To identify the extent of implementation of new solutions (innovation) in the material, institutional, and intellectual infrastructure.

The results of the study will help develop a model approach to innovation processes that determine the shaping of the local material, institutional, and intellectual infrastructure.

\section{Research area and methods}

\subsection{Research area}

The article assumes that the situation regarding the examined types of infrastructure is similar in most municipalities in Poland, i.e., few municipalities create infrastructure and implement innovation processes. The study subject is the Municipality of Myslenice, the ninth municipality in Malopolska in terms of the socio-economic development. The Myslenice municipality would rank higher if not for the fact that its average annual indebtedness indicator for communal budgets for 2014-2016 was high (96.5\%). Such indebtedness results from the high level of utilization of EU funds, which require the own contribution of the municipality. It is worth mentioning at this point that the Municipality of Myslenice was the fourth municipality in Malopolska as regards the use of EU funds in 2016. It was selected as a representative example, which can be used to create a model for other municipalities due to is high ranking positions. However, before the municipality was selected, pilot studies were carried out in the form of interviews with public administration employees who know the subject. The pilot studies were aimed at verifying the Myslenice municipality as a research area. Myslenice is an urban-rural municipality in the Lesser Poland Voivodeship, south Poland. The surface area of the municipality is $153.7 \mathrm{~km}^{2}$ with 43.411 residents.

\subsection{Methods}

The research structure was based on the use of qualitative methods. The cause and effect explanation procedures were used as leading tools. Among various sources of information, the method of conducting primary research (observations, interviews) and information from secondary sources were used. The research had two phases. The diagram of the study process is presented in Figure 1.

The first stage of the study involved literature research to formulate the primary goal and specific objectives. The second stage focused on the definition of the local material, institutional, and intellectual infrastructure based on the literature research. The third stage identified innovation processes and dependencies between the innovation process and the creation of the local material, institutional, and intellectual infrastructure based on the literature research, observations, and interviews. At the fourth stage, the authors drafted survey questionnaires supplemented by an interview. The studies were aimed at diagnosing and analyzing the use of innovation in the shaping of the local infrastructure and the measurement of the impact of innovation processes on the local development. The fifth stage was a discussion and the sixth, final, stage of the study involved analysis and assessment of collected information in order to formulate the model of local infrastructure creation. Recommendations were composed in this stage. 


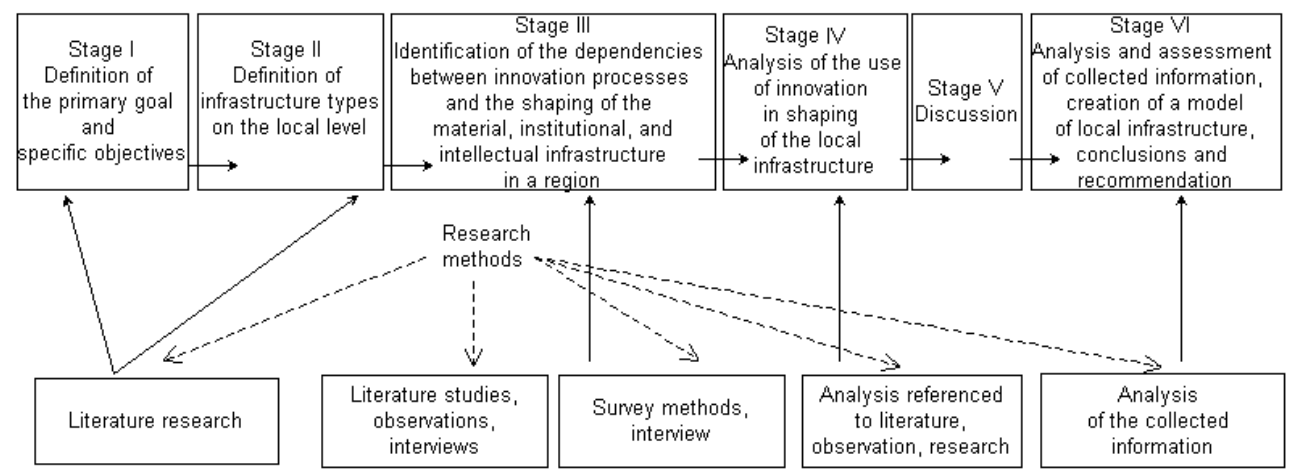

Figure 1. Stages of the study process (source: own work)

To verify these premises, we conducted a study among the residents, employees of the Myslenice municipality, and their managers. The research was carried out in two stages. In the first stage, interviews with experts were conducted to verify questions in the questionnaire. The interviews involved people working in the municipal office. Thirteen people took part in the interviews. It is $10 \%$ of the employees of the municipal office. When the first stage of the research was completed, the second stage was started. After the questions for the research questionnaire were prepared, studies were conducted among residents and people working in the municipal office. The minimum size of the sample was determined by the following formula (Szreder, 2004, p. 120):

$$
n=\frac{N \cdot\left[p^{2} \cdot f(1-f)\right]}{N \cdot d^{2}+p^{2} \cdot f(1-f)},
$$

where: $N$ - the size of the population to which the study relates (inference); $p$ - the confidence level for the results; $f$ - the size of the fraction; $d$ - the statistical error.

The sample size was 71 employees of the municipal office and 239 people living in the Myslenice municipality (25.300 residents) with a 90\% confidence level, 0.5 fraction, and a statistical error rate of $5 \%$. The questionnaires were delivered to 100 respondents working in the municipal office and to 500 residents. The return of correctly filled questionnaires was 90 pieces.

The added value of the article is the model of infrastructure construction in the material, intellectual, and institutional dimension along with recommendations for the Myslenice municipality.

\section{Material, institutional, and intellectual infrastructure and local, sustainable development}

A region is defined as a special kind of territory that shares common material, economical, functional, social, and even symbolic values (Rowe, 2019). The completeness and complexity of these values make the perspective for sustainable development of the given region taking into account the material and non-material specifics of nature, economy, and people in the 
area (Romao \& Neuts, 2017). The immanent feature of the region is its development, or the ability to make changes (Diebolt \& Hippe, 2019) in the political, economic, cultural, technological, or environmental dimensions (Indus, 2018).

Regional development can be defined as a steady increase in the standard of living and the economic potential of a large territorial unit (Lewandowska, Stopa, \& Humenny, 2015; Marynych, 2017). According to this approach, regional development can be considered in terms of quantitative and qualitative changes. Local development refers to changes taking place in a municipality or district. Still, according to many authors, this is a very complex concept, as it is sometimes defined differently (Marynych, 2017). After the country's threetier administrative division was introduced in Poland in 1999, regional development was recognized as a process of change that takes place in municipalities, cities, and counties. Local development in Poland as a socioeconomic category is not widely understood in scientific research, nor is there a long-standing tradition for it in the economic sciences. This category of development cannot, however, be regarded a complete novelty as local community actions or the rational use of local resources have always been present in the activities of local government units (Kotnik \& Kovac, 2018).

Regional development factors are those components and properties of regions and their environments, and the events that take place within them, that lead to the transition from simpler, less perfect regions to more complex and better forms or states (Głuszczuk, 2011). The impact of these factors can be compared to an infinite chain of causes and effects: every positive change (effect) has its origin (cause), and the effect creates new conditions in which the same or other causes initiate a sequence of events to open the premises for further transformations. In this process, several interrelated causes can be distinguished, the most important of which is the set of determinants of regional development. These determinants are classified in various ways, but in verifying their systematics, it is difficult not to account for the multifaceted nature of regional development (Głuszczuk, 2011).

Based on the literature analysis (Gawroński \& Prus, 2015; Popov, Omonov, Naumov, \& Veretennikova, 2018; Raszkowski \& Bartniczak, 2018), Figure 2 shows the determining factors for regional development ordered by three dimensions of the infrastructure (material, institutional, and intellectual).

By analyzing the determinants of regional development, we see that the factors presented are interweaving and mutually conditioned. Individual factors outside the structure of the region cannot be considered separately, as they may indeed present an opportunity for the region; whether they will be used properly depends on the decision-makers. For these reasons, the size and multiplicity of determinants of regional development in the global approach prompt an attempt to classify them in three infrastructural dimensions (groups), which are presented in Figure 2.

As shown in Figure 2, the material, institutional, and intellectual types infrastructure are interrelated and conditional; local (regional) development cannot be viewed by isolating any one infrastructure. The presented determinants can be classified into two groups as quantitative factors, also called resources, and qualitative, also referred to as efficiency. Quantitative (resource) factors refer to objectively existing resources in the region, derived from natural 
conditions and resulting from historical development (Indus, 2018). So, the first area is the material infrastructure of a region, which is formed by the region's natural (environmental), material (property), and technological resources (tools, means of work). Such quantitative factors undoubtedly have a significant impact on the development of the region as they are the primary source of its resources and wealth (Raszkowski \& Bartniczak, 2018).

The second area, the institutional infrastructure, includes activities undertaken by the parents, institutions (places where people meet and use specific services to meet their needs, such as schools, health centers, churches, day centers, social organizations, community centers, markets), and skills relevant to investments and implementation of EU Operational Programs. The quality of life of the local community depends on the number, diversity, and efficiency of institutions.

The third area is the intellectual infrastructure. Elements in this group are challenging to identify and measure because they are built on intellectual capital (the value of ideas and broadly understood knowledge) and social capital (attitudes, social awareness, skills, and qualifications). According to Coleman, social capital is a society that is characterized by trust, norms, and relationships through which management efficiency is enhanced (Coleman, 1988).

When referring social capital to the region's intellectual infrastructure, attention should be paid to combining social capital with civic engagement (Romao \& Neuts, 2017). As an example, we might distinguish the attitudes of citizens who are willing to sacrifice their time and money in good intentions and those who function in social isolation.

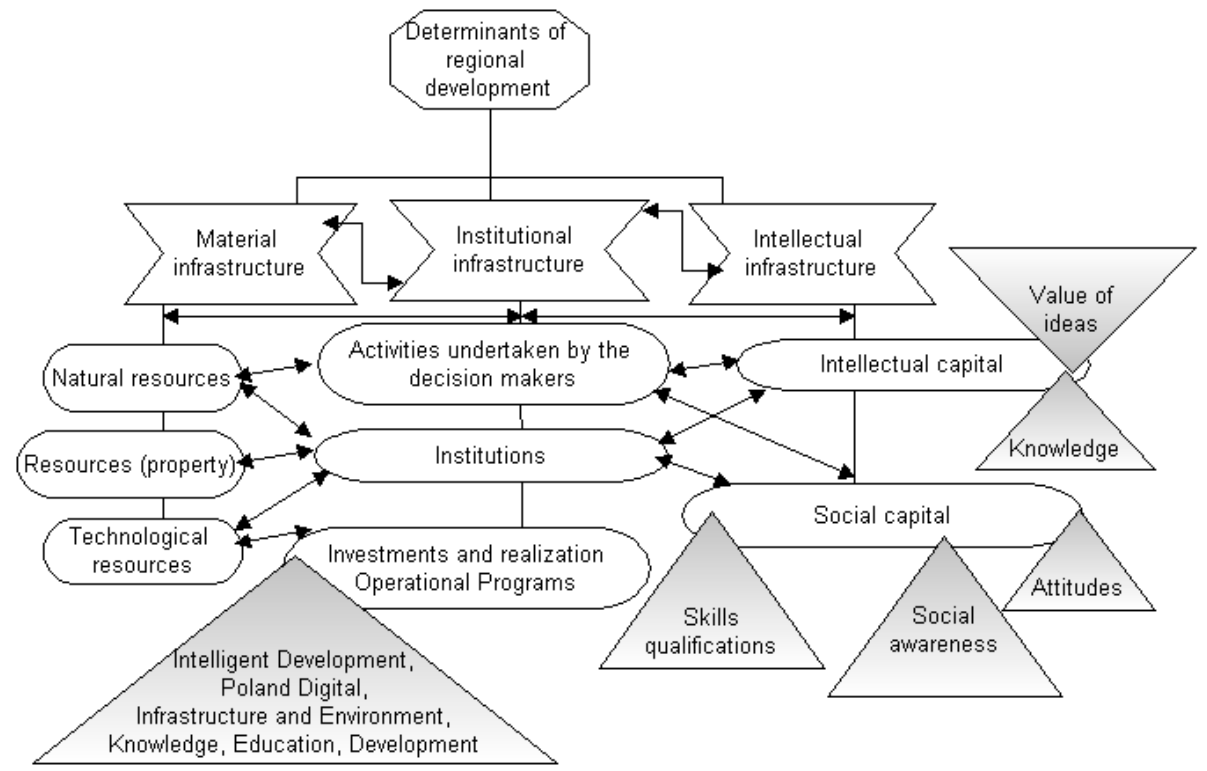

Figure 2. Determinants of regional development in three dimensions of infrastructure (source: own work) 
According to Fukuyama (2001), the main benefit of social capital is the reduction of transactional costs - that is the cost of contracting or formal action. At the same time, social capital contributes to the functioning of a healthy civil society and the creation of groups and associations between the state and the family, whereas its absence causes social dysfunctions and may lead to the lack of or reduction in economic development (Sierocińska, 2011). As outlined by extensive research, the growth or decline of social capital is effected by the spatial organization of the urban or rural environment. The community interaction and neighborhood communication facilitating planning and urban design of towns and other human settlements facilitate the growth of social capital (Mason, 2010). On the other hand, the loss of local or regional identity in the way urban environment is organized reduces human interactions and thus brings the social capital to the decline. Community design facilitates the growth of social capital and by this creates a more favorable economic climate in the community as it facilitates social and cultural integrity and supportiveness, shared facilities, and resources (Peiro-Palomino, 2016). Thus, when referring to social capital within the intellectual infrastructure of a region, attention should be paid to its connection to civic engagement, through which arise informal social networks that choose to sacrifice their time and money for the good of the society, as opposed to those who prefer to function in social isolation (Bjørnskov \& Méon, 2013).

As regards social capital for local (regional) development, we focus on three dimensions: effective solutions in formal activities, the intellectual capital of office workers, and the intellectual capital of residents and investors. Social capital consists of attitudes, skills and social awareness and on the other hand, it is intellectual capital understood as the value of ideas. The intellectual infrastructure of the region will, therefore, be built on trust, social bonds, information flow, social activity (cultural potential, attitudes, values), local identity, community organization, and social leaders (Głuszczuk, 2011). The material and institutional infrastructure is very important for regional development, but it primarily depends on the intellectual infrastructure.

To summarize this section, the ability to create and maintain competitive advantage depends on the so-called development resources (Esmaeilpoorarabi, Yigitcanlar, Guaralda, \& Kamruzzaman, 2018), including physical (natural) capital, institutional capital (management and management skills), intellectual capital (knowledge and value of ideas), and social capital (attitudes, public awareness, skills, and qualifications) all of which are closely related and mutually reinforcing. The material and institutional infrastructure is very important for regional development, but above all depends on the intellectual infrastructure (Coleman, 1988). The material infrastructure consists of natural, material, and technological resources used effectively by those in charge of local (regional) development. The implementation of modern technologies is of great importance in this area. The institutional infrastructure is actions taken by head administrators to foster regional development and the way head officers manage public institutions. The creation of the institutional infrastructure should be characterized by the implementation of New Public Management. The intellectual infrastructure is the intellectual capital (knowledge and value of ideas) and social capital (attitudes, social awareness, skills, and qualifications). Actions taken regarding the intellectual infrastructure may be related to the concept of good governance (Yu, 2018). When this principle is implemented to a large extent, it contributes to the social confidence in actions taken by the administration. 
Successful implementation of the principle of good governance is of key importance also from the point of view of building state's potential to create good conditions for the growth of civil society and entrepreneurship (Ministry of Regional Development [MRD], 2008).

The shaping of the types of infrastructure mentioned above requires modifying processes, products, techniques, and methods of operation that are perceived by the entire organization as new and progressive in a given field and lead to the increase of the efficiency of using resources at its disposal. Such activities are nothing more than broadly understood innovations. In the economic literature, the concept of innovation often refers mainly to the first applications of a given solution, whereas Pajestka (1975) believes that it does not matter whether products or technologies (as production methods) are known elsewhere; innovation is not only what is an absolute novelty on a global scale, but what is new to a given society (Pajestka, 1975). Thus, the next step will focus on the description of innovation processes at the local level.

\section{Specification of innovation processes at a local level}

The role of innovation in socioeconomic development was recognized by Friedrich List at the end of the nineteenth century. It was again taken up by Schumpeter (1934), whose valuable contribution to the development of the innovation theory and its role in economic development is the concept of innovation, whereby key innovations emerge cyclically and form the driving force of development. Technological innovations as an exogenous development factor have also emerged in the neoclassical model of development (Churski \& Dominiak, 2014). This model, which Dominiak and Churski (2012) based on Michael E. Porter's model, consists of three phases: development driven by key factors of production; investment-driven development; and innovation-driven development, including global competition and the creation of new technologies.

The innovation process is the emergence, maturation, and dissemination of new solutions, as well as their practical use, which produces specific economic and social effects (Saubanov, Nikolaev, \& Beliakin, 2017). The course of the innovation process can be compared to the life cycle of an organization (product, technology), which coincides with the four stages of arising, growth, maturity, and decline (Adizes, 1988).

When analyzing the trend of the life cycle of the innovation process, it can be noted that the process begins with an idea (the phase of the idea characterizes the phase of creation in the life cycle), then the process goes through thedesigning new solutions stage that can be technology, services, and even management. The next stage in the life cycle of the innovation process is the launch (dissemination, diffusion) that is the introduction of a new solution. The second and third stages characterize the organizational growth stage, which means that the indicators should change (e.g., GDP per capita, the level of social growth, the level of unemployment, employment in administration). The next stage is the imitation. Other organizations implement similar solutions (learn), which results in saturation with a new solution. It is very important at this stage to see that others are learning and applying similar solutions. To see saturation with a new solution should facilitate a fresh start from scratch, that is, a return to the idea phase. As stated by Adizes (1988), the disappearance of entrepreneurship and innovation causes the organization to collapse. The same applies to the implementation 
of innovation in a municipality, which must preserve the ability to change and implement new solutions if it wants to develop (Churski \& Dominiak, 2014). The maturity phase in the innovation process is the moment when a decision should be made to re-implement new solutions, and it is useful to use the model of innovative processes in a municipality (Figure 2). If no action is taken, no new ideas are submitted, the innovation will enter a phase of decline. A failure to implement new ideas will result in the organization's decline. It is important to pay attention to the fact that ideas can be reported and implemented all the time regardless of the phase of the innovation (Adizes, 1988; Bleicher, 1992, 1994; Greiner, 1972; Quinn \& Cameron, 1983).

As indicated above, innovations are among the key processes in an organization. Without introducing new products or modifying production processes, the organization is not able to survive regardless of whether it is a company, association, or a municipality. For these reasons, in order to offer an answer to the question about the influence of innovation processes on the creation of the material, institutional, and intellectual infrastructure, Figure 3 presents a model of these relationships.

The model presented in Figure 3 is a very important solution when the innovation processes in the municipality or region are in the phase of maturity or decline, or when they are not completely visible. An analysis of the relationships shown in Figure 2 reveals that the creation of the material, institutional, and intellectual infrastructure determines regional development and is strictly dependent on innovation processes. The innovation process starts with the creation and submission of ideas and leads to the selection of an idea and its implementation. Specifically, the process begins at stage I, when a decision is made to introduce an idea - a solution to a problem - that should be accepted by the social system and the people affected. If the solution is accepted, stage II occurs, in which information on the implementation of the idea is acquired and the decision to accept or reject the idea is made. If the idea is discarded, the process reverts back to stage I; if it is accepted, stage III begins. This stage involves the collection of additional information, corrections, employee change, acquisition of new skills and habits, and stabilization of the social system. This model is paired with the information with which it creates the ecosystem; in other words, it cannot build the material, institutional, and intellectual infrastructure without information (in principle, knowledge, or adequately used information). On the one hand, the information is collected from the environment and used; on the other hand, it is transmitted to the environment in the form of messages and analyses of regional development and its determinants.

According to Figure 3, if the analyzed types of infrastructure are well developed in a region, innovation processes are only natural there, which is reflected in regional development. The article assumes that innovation processes affect the shaping of the infrastructure because according to the Ministry of Regional Development, governance standards in Poland are significantly behind other European and global states in terms of the implementation of good governance principles. Governance performance measured by the quality of civil service and its independence from political pressure, quality of creation and implementation of policies, and the credibility of government commitment to the implementation of the policies indicate institutional weakness in Poland in this area compared to the EU average (MRD, 2008). 


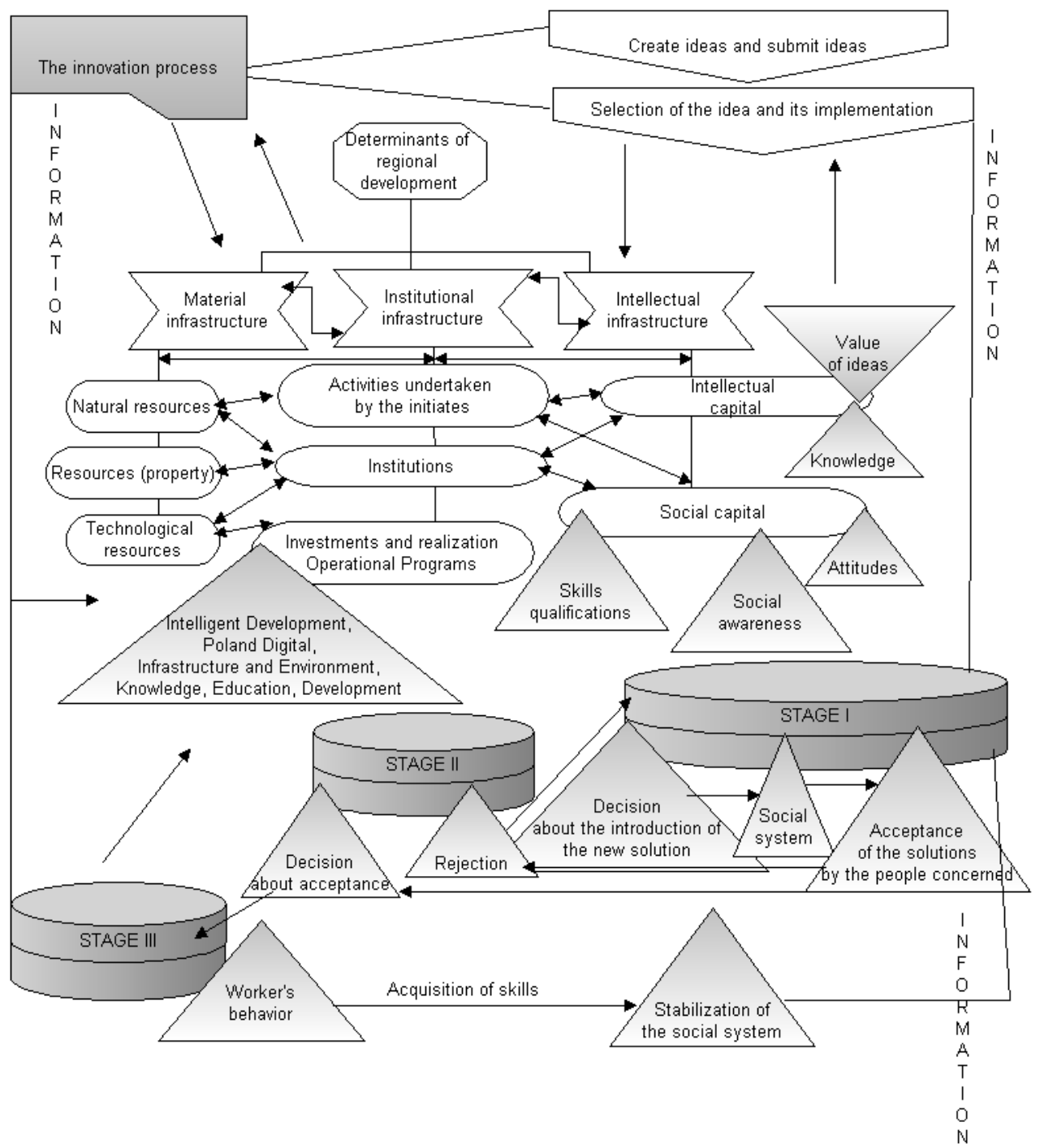

Figure 3. The dependencies between innovation processes and the material, institutional, and intellectual infrastructure in a region (source: own work)

\section{Results}

The authors conducted their study in the Myslenice municipality to achieve the primary objective and specific objectives. The study involved a questionnaire that consisted of three parts (background of the interviewee, questions about the influence of innovation processes on the creation of regional infrastructure and on regional development and the questions based on a five-point Likert scale). The first part focused on the background of the interviewee. It facilitated a precise definition of the investigated group. Among the 100 respondents, $40 \%$ were public administration officers (municipality officers, local officers, headmasters, and 
teachers - PA) and 60\% were residents (R). Forty-one per cent of them declared higher education, 35\% secondary education, $15 \%$ vocational education, and $9 \%$ a bachelor degree. It was important to identify the sample population because later in the study, correlations were analyzed between responses and the education background and between responses and the subgroup: public administration and respondents. There was no correlation between the level of education and responses, but there were differences in responses between officers and residents. They are discussed further in the study.

The second part of the questionnaire contained questions about the influence of innovation processes on the creation of regional infrastructure (material, institutional, and intellectual) and on regional development. This part of the questionnaire included questions about the inhibitors of innovation processes. The possible responses here were yes, no, I don't know. The results are shown in Figure 4.

According to Figure 4, local innovation processes are limited by financial barriers, affect regional development, and managers should use innovation processes to create infrastructure (a significant majority of positive responses). The responses did not offer an unambiguous answer whether those in charge of municipalities create the infrastructure based on innovation processes and whether the psychosocial aspect is a restraint for local innovation processes (about $40 \%$ of the respondents neither agreed nor disagreed with the statement, $40 \%$ of the respondents believed the psychosocial aspect is not a barrier for innovation processes, and $40 \%$ of the respondents believed managers to create the infrastructure based on innovation processes). The responses did not facilitate an unambiguous conclusion regarding psychosocial barriers or whether managers in public institutions use innovation processes to create infrastructure.

As was mentioned above, the second part of the questionnaire included a question about the dynamics of innovation processes in the investigated region. The respondent data section contained a question about the dynamics of innovation processes in the investigated region.

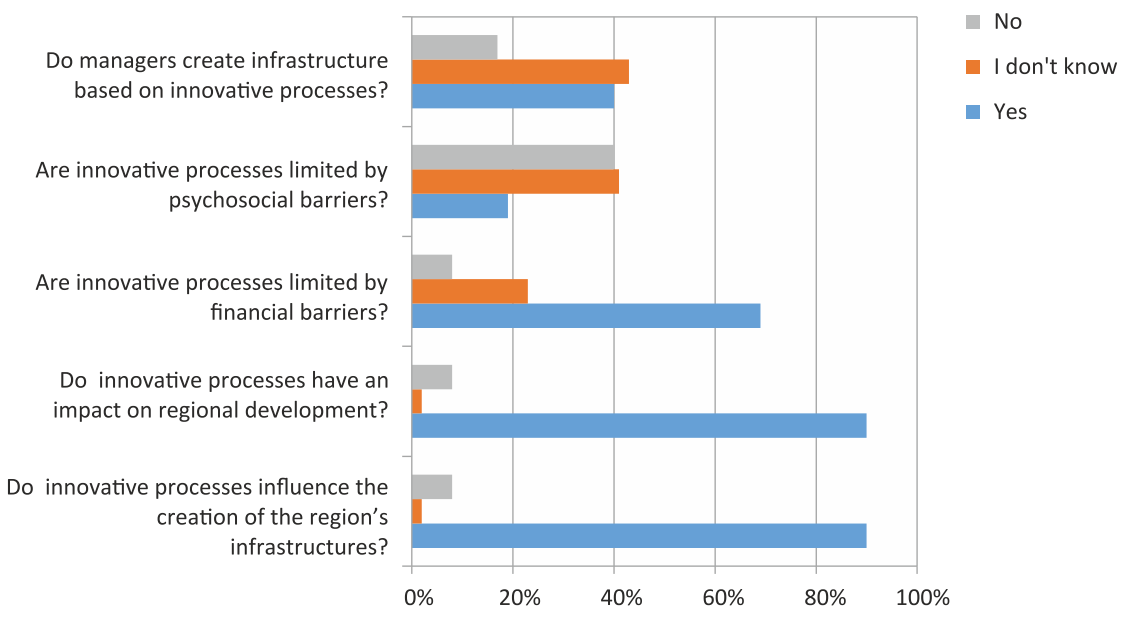

Figure 4. Local innovation process restraints and their influence on the development of a region (source: own work) 
The respondent selected one response from among the following: Very high dynamics, high dynamics, average dynamics, low dynamics, very low dynamics. Fifty-five percent of the respondents described the innovation processes in the municipality as having average dynamics, $19 \%$ as high dynamics, $8 \%$ as very high dynamics, $6 \%$ as very low dynamics, and $2 \%$ as low dynamics (90\% of the respondents who worked in public administration believed the dynamics of the innovation processes in the region to be average and $10 \%$ indicated low dynamics).

To summarize the results, regional managers should implement innovative processes in their regions. As for the barriers to implementing innovative processes, attention should be paid to attracting financial resources, raising awareness, and shaping psychosocial determinants (e.g., changes in leadership, incentive systems, stimulation of innovation or changes) of innovation processes.

The third and final part of the questionnaire consisted of questions based on a five-point Likert scale. The questions for the questionnaire were prepared based on the literature study. They concerned local innovation (new solutions) in the material, institutional, and intellectual infrastructure, and were divided into three groups. As the material infrastructure was defined as the use of natural, material, and technological resources, the questions in this part of the questionnaire concerned the introduction of new technological solutions and the creation of technology. The institutional infrastructure was defined as new solutions in the area of management (the implementation of the New Public Management). Hence this part of the questionnaire included questions about the introduction of new solutions in the area of management. Good governance is a notion that significantly affects the creation of intellectual infrastructure. This is why this part of the questionnaire included questions about new solutions and action regarding the creation of civil society and the activity of social leaders.

Questions in the questionnaire became encoded variables that were subject to factor analysis. The factor analysis was used in the study to group the variables, which was useful to infer about the structure of the studied phenomenon, i.e., in the search for general regularities in the analyzed phenomenon. As a result of the factor analysis, several main factors of decisive importance were obtained from the original large set of variables (Madhavan, Sobczyk, \& Ang, 2018). As a result of the analysis, the variables were grouped according to the frequency of their occurrence. The actions that are taken, taken sometimes and not taken in the municipality were extracted. This facilitated further studies to develop generalizations.

Moreover, to test whether there was a relation between the age, education, and the structure of responses, the Pearson's linear correlation coefficient was used. The value of the coefficient was equal to 0.1 , which is indicative of a weak correlation. It has been concluded that the responses in the questionnaire did not depend on the age or education of the respondents. The factors included in the questionnaire were treated as random variables, integers. Therefore the median and modal values were given in the description. Although there was no correlation between the responses of respondents and their age or education in the questionnaire, there were some striking differences between the responses of residents (R) and those of PA employees, as shown in Table 1. On the other hand, Figure 5 presents the results of research on selected most important activities in the area of construction of the discussed types of infrastructure (two actions in the field of the material, institutional, and intellectual infrastructure) in local development. The first chart shows the responses given by people working in public administration and the second, by residents. 
Table 1. Innovation processes in regional infrastructure development (in percentages) (source: own study based on the research)

\begin{tabular}{|c|c|c|c|c|c|c|c|c|c|c|}
\hline \multirow{3}{*}{ The innovation process } & \multicolumn{10}{|c|}{ Value scale } \\
\hline & \multicolumn{2}{|c|}{1} & \multicolumn{2}{|c|}{2} & \multicolumn{2}{|c|}{3} & \multicolumn{2}{|c|}{4} & \multicolumn{2}{|c|}{5} \\
\hline & $\mathrm{R}$ & $\mathrm{PA}$ & $\mathrm{R}$ & $\mathrm{PA}$ & $\mathrm{R}$ & $\mathrm{PA}$ & $\mathrm{R}$ & $\mathrm{PA}$ & $\mathrm{R}$ & PA \\
\hline \multicolumn{11}{|c|}{ MATERIAL INFRASTRUCTURE } \\
\hline $\begin{array}{l}\text { Are new technologies implemented } \\
\text { in the municipality? }\end{array}$ & 1.9 & 2.8 & 31.5 & 30.6 & 35.1 & 36.1 & 25.9 & 25.0 & 5.6 & 5.5 \\
\hline $\begin{array}{l}\text { Does the municipality create its own } \\
\text { new technological solutions (such as } \\
\text { e-services, newsletter)? }\end{array}$ & 18.5 & 19.4 & 33.3 & 33.3 & 29.6 & 30.6 & 11.1 & 11.1 & 7.5 & 5.5 \\
\hline $\begin{array}{l}\text { Does the municipality purchase IT } \\
\text { applications? }\end{array}$ & 5.6 & 5.5 & 37.0 & 38.9 & 27.8 & 27.8 & 24.0 & 25.0 & 5.6 & 2.8 \\
\hline $\begin{array}{l}\text { Are new services deployed in the } \\
\text { municipality using new equipment? }\end{array}$ & 5.6 & 5.5 & 18.5 & 19.4 & 42.6 & 41.7 & 29.6 & 30.6 & 3.7 & 2.8 \\
\hline $\begin{array}{l}\text { Are e-services introduced in the } \\
\text { municipality? }\end{array}$ & 9.3 & 8.3 & 33.3 & 33.3 & 27.8 & 27.8 & 25.9 & 25.0 & 3.7 & 5.5 \\
\hline \multicolumn{11}{|c|}{ INSTITUTIONAL INFRASTRUCTURE } \\
\hline $\begin{array}{l}\text { Has the quality of service provided } \\
\text { in the municipality improved? }\end{array}$ & 1.9 & 41.7 & 27.8 & 38.9 & 27.8 & 19.4 & 31.4 & 0.0 & 11.1 & 0.0 \\
\hline $\begin{array}{l}\text { Does the management in the } \\
\text { municipality change the way } \\
\text { decisions are made? }\end{array}$ & 5.6 & 5.5 & 14.8 & 13.9 & 46.3 & 47.2 & 31.4 & 30.5 & 1.9 & 2.8 \\
\hline $\begin{array}{l}\text { Is there a risk involved in the } \\
\text { actions (decisions) taken in the } \\
\text { municipality? }\end{array}$ & 3.7 & 5.5 & 33.3 & 33.3 & 24.0 & 25 & 29.6 & 30.5 & 9.4 & 5.5 \\
\hline $\begin{array}{l}\text { Are modern management methods } \\
\text { used in the municipality? }\end{array}$ & 18.5 & 61.1 & 25.9 & 38.9 & 27.8 & 0.0 & 20.4 & 0.0 & 7.5 & 0.0 \\
\hline $\begin{array}{l}\text { Have operational programs been } \\
\text { implemented in the municipality? }\end{array}$ & 9.3 & 11.1 & 27.8 & 88.9 & 25.9 & 0.0 & 27.8 & 0.0 & 9.3 & 0.0 \\
\hline $\begin{array}{l}\text { Does the management analyze the } \\
\text { needs of the public when selecting } \\
\text { projects to be implemented? }\end{array}$ & 13.0 & 22.2 & 25.9 & 77.8 & 31.4 & 0.0 & 20.4 & 0.0 & 9.3 & 0.0 \\
\hline $\begin{array}{l}\text { Does the management know how to } \\
\text { use operational programs? }\end{array}$ & 11.1 & 11.1 & 22.2 & 22.2 & 33.3 & 33.3 & 25.9 & 25.0 & 7.5 & 8.3 \\
\hline $\begin{array}{l}\text { Do the activities of the municipality } \\
\text { influence the development of the } \\
\text { region? }\end{array}$ & 3.7 & 2.8 & 24.0 & 25.0 & 31.4 & 30.6 & 29.6 & 30.6 & 11.1 & 11.1 \\
\hline $\begin{array}{l}\text { Do the ingenuity and opinion of the } \\
\text { public determine the functioning of } \\
\text { the municipality? }\end{array}$ & 11.1 & 11.1 & 29.6 & 22.2 & 31.4 & 0.0 & 22.2 & 0.0 & 5.6 & 0.0 \\
\hline \multicolumn{11}{|c|}{$\begin{array}{ll}\text { INTELLECTUAL INFRASTRUCTURE } \\
\end{array}$} \\
\hline $\begin{array}{l}\text { Are ideas created and collected in } \\
\text { the municipality? }\end{array}$ & 3.7 & 2.8 & 14.8 & 16.6 & 51.9 & 52.8 & 25.9 & 25 & 3.7 & 2.8 \\
\hline $\begin{array}{l}\text { Are some of the ideas selected for } \\
\text { implementation in the municipality? }\end{array}$ & 5.6 & 5.5 & 24.0 & 25.0 & 46.3 & 44.4 & 18.5 & 19.4 & 5.6 & 5.5 \\
\hline
\end{tabular}


Continue of Table 1

\begin{tabular}{|c|c|c|c|c|c|c|c|c|c|c|}
\hline \multirow{3}{*}{ The innovation process } & \multicolumn{10}{|c|}{ Value scale } \\
\hline & \multicolumn{2}{|c|}{1} & \multicolumn{2}{|c|}{2} & \multicolumn{2}{|c|}{3} & \multicolumn{2}{|c|}{4} & \multicolumn{2}{|c|}{5} \\
\hline & $\mathrm{R}$ & PA & $\mathrm{R}$ & PA & $\mathrm{R}$ & PA & $\mathrm{R}$ & PA & $\mathrm{R}$ & PA \\
\hline $\begin{array}{l}\text { Are the ideas of people working in } \\
\text { the municipality office used? }\end{array}$ & 7.5 & 77.8 & 29.6 & 22.2 & 46.3 & 0.0 & 9.3 & 0.0 & 7.5 & 0.0 \\
\hline $\begin{array}{l}\text { Is the flow of information in the } \\
\text { municipality smooth? }\end{array}$ & 20.4 & 77.8 & 20.4 & 22.2 & 42.6 & 0.0 & 14.8 & 0.0 & 1.9 & 0.0 \\
\hline $\begin{array}{l}\text { Is communication between the } \\
\text { municipality office, residents, and } \\
\text { investors open? }\end{array}$ & 14.8 & 11.1 & 33.3 & 88.9 & 29.6 & 0.0 & 16.7 & 0.0 & 5.6 & 0.0 \\
\hline $\begin{array}{l}\text { Do municipality office employees } \\
\text { improve their qualifications } \\
\text { (training, studies)? }\end{array}$ & 9.3 & 8.3 & 9.3 & 11.1 & 40.7 & 41.7 & 29.6 & 27.8 & 11.1 & 11.1 \\
\hline $\begin{array}{l}\text { Does the public have confidence in } \\
\text { the leaders of the municipality? }\end{array}$ & 20.4 & 22.2 & 24.0 & 25.0 & 37.0 & 36.1 & 9.3 & 8.3 & 9.3 & 8.3 \\
\hline $\begin{array}{l}\text { Does the local community share } \\
\text { a specific set of values and ethical } \\
\text { norms? }\end{array}$ & 11.1 & 11.1 & 11.1 & 11.1 & 48.1 & 47.2 & 20.4 & 22.2 & 9.3 & 8.3 \\
\hline $\begin{array}{l}\text { Are citizens involved in what is } \\
\text { happening in the municipality? }\end{array}$ & 7.5 & 5.5 & 9.3 & 11.1 & 46.3 & 47.2 & 20.4 & 19.4 & 16.7 & 16.6 \\
\hline $\begin{array}{l}\text { Do citizens support the } \\
\text { implementation of actions } \\
\text { undertaken in the municipality? }\end{array}$ & 9.3 & 11.1 & 18.5 & 16.6 & 37.0 & 36.1 & 29.6 & 30.6 & 5.6 & 5.5 \\
\hline $\begin{array}{l}\text { Does the local community take } \\
\text { an active part in the life of the } \\
\text { municipality? }\end{array}$ & 3.7 & 5.5 & 18.5 & 19.4 & 31.5 & 30.6 & 33.3 & 33.3 & 13.0 & 11.1 \\
\hline $\begin{array}{l}\text { Does the municipality have a local } \\
\text { identity? }\end{array}$ & 1.9 & 2.8 & 18.5 & 19.4 & 31.5 & 30.6 & 40.7 & 41.7 & 7.5 & 5.5 \\
\hline $\begin{array}{l}\text { Are social leaders active in the } \\
\text { municipality? }\end{array}$ & 1.9 & 0.0 & 24.0 & 0.0 & 33.3 & 0.0 & 33.3 & 77.8 & 7.5 & 22.2 \\
\hline $\begin{array}{l}\text { Do social leaders support actions } \\
\text { taken by the municipality? }\end{array}$ & 5.5 & 0.0 & 22.2 & 0.0 & 27.8 & 0.0 & 33.3 & 77.8 & 11.1 & 22.2 \\
\hline $\begin{array}{l}\text { Do social leaders act independently } \\
\text { and build civil society? }\end{array}$ & 5.5 & 0.0 & 20.4 & 0.0 & 35.1 & 0.0 & 25.9 & 88.9 & 13.0 & 11.1 \\
\hline $\begin{array}{l}\text { Are municipality office employees } \\
\text { resident and investor-oriented? }\end{array}$ & 9.3 & 0.0 & 22.2 & 0.0 & 38.9 & 0.0 & 24.0 & 88.9 & 5.6 & 11.1 \\
\hline $\begin{array}{l}\text { Does the municipality office care } \\
\text { about building relationships with } \\
\text { residents and investors? }\end{array}$ & 7.5 & 0.0 & 20.4 & 0.0 & 44.4 & 0.0 & 20.4 & 88.9 & 7.5 & 11.1 \\
\hline $\begin{array}{l}\text { Does the way people are led change } \\
\text { in the municipality office? }\end{array}$ & 11.1 & 88.9 & 27.8 & 11.1 & 40.7 & 0.0 & 11.1 & 0.0 & 9.3 & 0.0 \\
\hline $\begin{array}{l}\text { Are incentive systems in the } \\
\text { municipality office changing? }\end{array}$ & 18.5 & 77.8 & 20.4 & 22.2 & 44.4 & 0.0 & 13.0 & 0.0 & 3.7 & 0.0 \\
\hline $\begin{array}{l}\text { Are the procedures in the } \\
\text { municipality offices changing? }\end{array}$ & 9.3 & 8.3 & 16.7 & 16.6 & 51.8 & 52.8 & 16.7 & 16.6 & 5.6 & 5.5 \\
\hline
\end{tabular}


End of Table 1

\begin{tabular}{|l|c|c|c|c|c|c|c|c|c|c|}
\hline \multirow{2}{*}{ The innovation process } & \multicolumn{7}{|c|}{ Value scale } \\
\cline { 2 - 14 } & \multicolumn{2}{|c|}{1} & \multicolumn{2}{|c|}{2} & \multicolumn{2}{|c|}{3} & \multicolumn{2}{|c|}{4} & \multicolumn{2}{c|}{5} \\
\cline { 2 - 13 } & $\mathrm{R}$ & $\mathrm{PA}$ & $\mathrm{R}$ & $\mathrm{PA}$ & $\mathrm{R}$ & $\mathrm{PA}$ & $\mathrm{R}$ & $\mathrm{PA}$ & $\mathrm{R}$ & $\mathrm{PA}$ \\
\hline $\begin{array}{l}\text { Is the scope of responsibility set in } \\
\text { the municipality office? }\end{array}$ & 7.5 & 8.3 & 20.4 & 22.2 & 40.7 & 38.9 & 20.4 & 19.4 & 11.1 & 11.1 \\
\hline $\begin{array}{l}\text { Are decision-making competencies } \\
\text { delegated to lower-tier officers in } \\
\text { the municipality office? }\end{array}$ & 20.4 & 88.9 & 16.7 & 11.1 & 38.9 & 0.0 & 18.5 & 0.0 & 5.5 & 0.0 \\
\hline $\begin{array}{l}\text { Are experience and creativity } \\
\text { combined in the municipality office? }\end{array}$ & 16.7 & 88.9 & 22.2 & 11.1 & 38.9 & 0.0 & 13.0 & 0.0 & 9.3 & 0.0 \\
\hline $\begin{array}{l}\text { Are new solutions tried in the } \\
\text { municipality? }\end{array}$ & 20.4 & 88.9 & 22.2 & 11.1 & 40.7 & 0.0 & 13.0 & 0.0 & 3.7 & 0.0 \\
\hline $\begin{array}{l}\text { Are employees of the municipality } \\
\text { office evaluated? }\end{array}$ & 9.3 & 0.0 & 11.1 & 77.8 & 51.8 & 22.2 & 20.4 & 0.0 & 7.5 & 0.0 \\
\hline $\begin{array}{l}\text { Are municipality office employees' } \\
\text { attitudes changing (become more } \\
\text { open)? }\end{array}$ & 11.1 & 0.0 & 24.0 & 0.0 & 33.3 & 0.0 & 24.0 & 100.0 & 7.5 & 0.0 \\
\hline
\end{tabular}

Note: R - responses of residents; PA - responses of public administration employees.

As was mentioned at the beginning of this section, there were differences between responses in the third part of the questionnaire given by officers and residents. To make them clearer, they are juxtaposed in Figure 5.

According to Figure 5, the implementation, creation, and use of modern technologies, as well as the improvement of qualifications by public administration employees, were assessed similarly by people working in public administration and by residents. All of these activities were assessed by the respondents as not undertaken or sometimes undertaken.

During the assessment by the public administration employees of the area concerning the improvement of services, the influence of the local community on the decisions regarding implemented projects, and communication with residents and investors, it turned out that no relevant actions are taken. Actions in the area of raising qualifications by persons working in public administration were assessed by them as taken, which may indicate employee awareness of the importance of building social capital in administrative structures.

The area of cooperation with social leaders was rated the highest by the employees of public administration (100\% of respondents answered that the activities of public institutions were supported by social leaders).

Inhabitants assessed activities such as: improving service quality, the impact of the local community on the decisions made regarding the implementation of projects, and communication with residents and investors far better than public administration employees. In the assessment of the measures above, the residents' responses indicated that actions were taken or partially taken. This may indicate that residents perceive activities in the areas mentioned above differently than public administration employees. The residents' ratings may also be higher because they use the services of the office, so they know better whether the quality of the services or communication changes. 


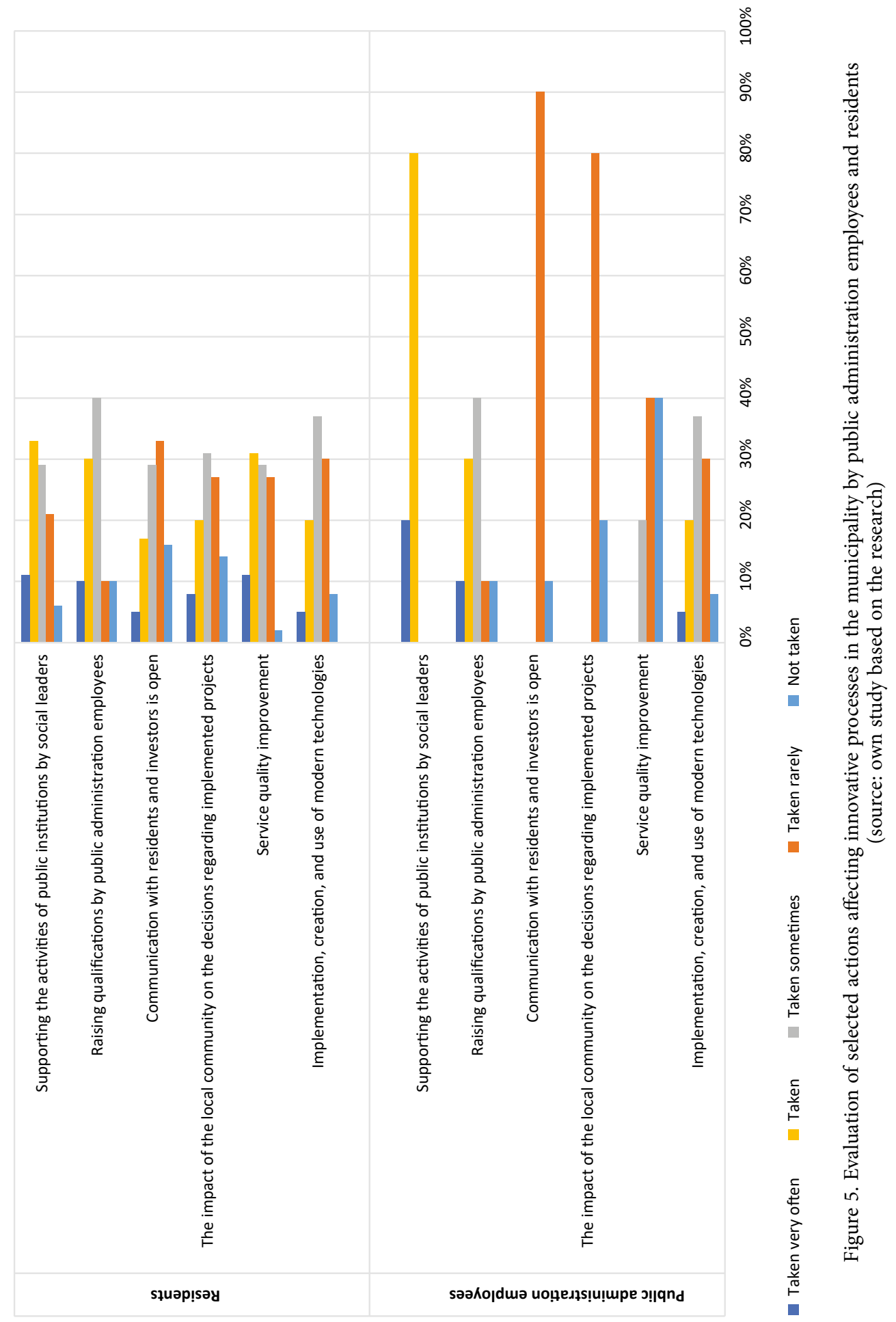


As regards the activities in the area of cooperation with social leaders, $60 \%$ of residents responded that there was no cooperation or it was only partial. In this case, the difference in responses may be because public administration employees have direct contact with social leaders and it is easier for them to define the contribution of social leaders to the activities undertaken for civil society.

\section{Discussion}

Innovation processes can be described as facilitators of the construction of the material, institutional, and intellectual infrastructure. This could be observed at the local level, with innovation infrastructures made available to local governments by higher-level governments and other stakeholders, often under labels different than "innovation". Locals might not be aware of the existence of infrastructure or its potential to foster innovation. Furthermore, we could observe that the categories of infrastructure distinguished at the outset, i.e., material, cognitive/intellectual and organizational/institutional infrastructure, were recognized as relevant by informed locals as well as by the current authors as external academic observers. These different types of infrastructure shaped each other over time. Their interdependence was different per case, per type of innovation and per community (Bichai, Kajenthira Grindle, \& Murthy, 2018; Purkus, Hagemann, Bedtke, \& Gawel, 2018). It could be observed, however, that all three types were needed, and that negative and positive feedback loops can be expected with regards to the effects of the three types of infrastructure on the actual innovation process. Once one type of infrastructure is undermined or weak, it will erode to make room for the other ones. The general effect will be a reduction in the chance of innovations to emerge and to survive. Institutional frameworks have to be in place for innovations to be observed, to appear legitimate (not just a deviation from the prevailing order), and to become institutionalized themselves, i.e., to influence the governance system, become routinized and distributed. The role of such institutionalization again depends on the type of innovation (Coenen, Asheim, Bugge, \& Herstad, 2017; Van der Voet, 2017). Author's observations suggest that the innovations in the creation of the three types of infrastructure are not manifested enough. This shows that modern technologies are not used a lot in the investigated region. No new management solutions are visible as well.

Our observations of regional development also indicate that each region is different in this respect: different types of innovation are likely to emerge; different types of innovation are more useful than others (more likely to make a difference in a particular context). The first reason is the always unique configuration of the three types of infrastructure (Kooij, Van Assche, \& Lagendijk, 2014; Vergragt, 2017). The second reason was the unique forms of multi-level governance which de facto exist in each region, hence the different relations between local and regional innovation, and between local and regional innovation infrastructure (Kuhlmann \& Ordóñez-Matamoros, 2017; Wu, Zhuo, \& Wu, 2017). In other words, what is useful for a local community to foster innovation always hinges on the regional conditions and innovation infrastructure (and vice versa). Still, such dependencies and mutual support will take different forms in each case. This also leads to the idea that "infrastructure" does not exist outside the innovation process itself, or, in other words, that it cannot be recognized 
as an abstract, but emerges in actual processes. The process, which in some cases allows for the inference that it could also function to foster innovation more generally, but such inference has to be made cautiously (Latour, 1992). One reason being, again, the always-different forms of multi-level governance, and in this, the functioning of some aspects of governance or development at one scale, as infrastructure for the other scale (Kelly, Ellis, \& Flannery, 2018; Noboa \& Upham, 2018). What this is, cannot be predicted.

One can usually observe a posteriori that local innovation found support at a regional or national level (in administration, in the financial, or economic sense), and vice versa. A regional innovation will identify what is useful to it at the national and local level, and some of its features will start to function as infrastructure. Our respondents revealed a wide variety of factors at other scales which proved to be relevant to innovation, and which proved to function as innovation infrastructure. Also, we also noticed that not all types of innovation infrastructure at other scales could be observed as such by insiders; they were sometimes normalized, considered as features of the "normal" environment, and not reflected upon as influencing innovation. This also means that local lobby or local participation in regional governance does not necessarily lead to more complete or context-appropriate innovation infrastructure; decisions on improvements of such infrastructure towards a more innovative region and locale, require a diversity of points and scales of observation as well as both insider and outsider knowledge (Van Assche et al., 2017; Van Assche \& Hornidge, 2015).

We could further observe and deduce that innovation paths remain unpredictable, even with insights into the strengths and weaknesses of the local/regional innovation infrastructure. The same national incentives play out well in one region and fail in another. In the region where the incentive found fertile ground, it led to innovation. The innovation path can still lead in many directions (U. Djanibekov, Van Assche, Boezeman, Villamor, \& N. Djanibekov, 2018; Novalia, Brown, Rogers, \& Bos, 2018). One reason is the co-evolution of many elements in an innovation or transition pathway, including the co-evolution of the different afore-mentioned types of infrastructure and the co-evolution of different scales in governance (Jedwab, Kerby, \& Moradi, 2017; Van Assche, Beunen, Duineveld, \& Gruezmacher, 2017). These co-evolutions imply that things happening far away can have an effect on a local innovation context, reshape it, and hence affect the innovation path. Moreover, the innovation path will be affected by, and partly embedded in, broader governance paths (Beeton \& Galvin, 2017; Zhan, de Jong, \& de Bruijn, 2017).

The innovation network is a concept that can be used here, reinterpreted, to signify the sum of types of innovation infrastructure; it can function as infrastructure itself (cf. Geels, 2002). Innovation networks then include particular relations between intellectual, institutional, and material infrastructure and those types of infrastructure themselves. In order to function, to be proper innovation networks, they likely need to link with, overlap with, governance networks. If in governance there is little awareness of the actual innovation processes and networks in the region, then the chances are slight that decisions, plans, policies made in governance will effectively reinforce innovation infrastructures. Conversely, if innovation networks are entirely decoupled from governance networks, then the innovators cannot easily institutionalize or mainstream a particular innovation, nor can they enhance the conditions for further innovation. Not linking innovation and governance networks makes 
innovation less likely, and more fragile (Biemans, 2018; Schramm, Kerber, Trapp, Zimmermann, \& Winker, 2017). For these reasons, the importance of the governance for the creation of the institutional infrastructure and the implementation of innovation processes cannot be overemphasized.

Despite the valid argument of various interacting infrastructures helping the innovation process and vice versa, see above, and see the typical example of Silicon Valley, infrastructure does not only enable path creation but also fosters path dependence (Agrawal, Galasso, \& Oettl, 2017). This essential point emerges from the same set of Polish observations as the previous one. Various types of infrastructure make it both easier and more difficult to innovate. A choice of a pathway, or an emergent pathway subsequently supported by governance decisions, also an innovation path, leads in a particular direction. The ambiguity of the concept of the innovation infrastructure asserts itself: infrastructure enables innovation yet keeps it on a track, excluding other (Oyelaran-Oyeyinka, 2017; Van Assche, Beunen, \& Duineveld, 2013). Innovation infrastructure, therefore, always has the potential to hamper innovation. In addition, if innovation of some sort is at a premium, it is likely that the existing qualities will be forgotten, and if innovation of one sort is preferred or coming out of a particular procedure, network, based on a particular infrastructure, then this will shape the ways of thinking, organizing, commercializing, regulating, for innovations. Alternatively, in other words, there is always a selectivity and a trade-off (Buck \& While, 2017; Kuhlmann \& Ordóñez-Matamoros, 2017).

Perfect innovation systems cannot exist. The imperfection has to be managed in order to keep fostering regional development. It is not an argument to drop the innovation concept, and it is not an argument to drop the idea of regional development. Pointing at future research directions, we would like to mention the possibility of distinguishing more systematically different types of innovation, each requiring different infrastructure. Scientific innovation is not the same as technological innovation, is not the same as organizational/ institutional innovation, is not the same as social innovation or economic innovation, and is not the same as an economic success (Kooij et al., 2014). Moreover, even within the realm of scientific innovation, the infrastructure needed to elevate the level and intensity of discovery will differ greatly: labs needed? particle accelerators? Large groups of people? Difficult prerequisite knowledge? The different types of innovation can build on each other but not necessarily. A new product, making more money is not always a better product. The innovation can be in the production networks, marketing, etc. The role of technology has to be singled out here, as reducing innovation to the development, selling, and application (e.g., in public administration) of technology, ignores the complexity of the process of innovation, its diversity, the diverse types of innovation infrastructures (where technology sometimes is the innovation, in other cases an infrastructure). Also, one has to keep track of both path creation and path dependence in technology development and application, as well as the potential effects of new administrative technologies to stifle creativity and innovation (Garud, Kumaraswamy, \& Karnoe, 2010).

The types of infrastructure themselves have many possible effects, enabling and disabling innovation or some sorts of innovation, not other ones. And they can have contradictory effects at the same time: a road has a broad impact; electricity can be used for many things. 
Universities (as knowledge infrastructure) can teach science related to a particular innovation also to management people saying that innovation is not necessary or opponents to that innovation, for social, environmental, and other reasons. So, infrastructure facilitates connectivity and mobility but also multiple mobilities and uses; it is per definition polyvalent, while the innovation process is per definition multi-dimensional. Therefore, infrastructure affects innovation in different ways, at the same time.

Governance, in the end, is the crux. The design and redesign of governance systems offer the best chance to foster, amplify, and protect innovation and innovation capacity. Shifting multi-level governance configurations and configurations at one levels is always tampering with innovation networks, and, therefore, has to be carried out with the greatest care and in the deepest awareness of the functioning of the current innovation systems and infrastructure (Cooke, Heidenreich, \& Braczyk, 2004; Lee \& Jung, 2018).

The study yielded a model that should be useful for creating local infrastructure with recommendations for the investigated municipality. It is exemplified in Figure 6.

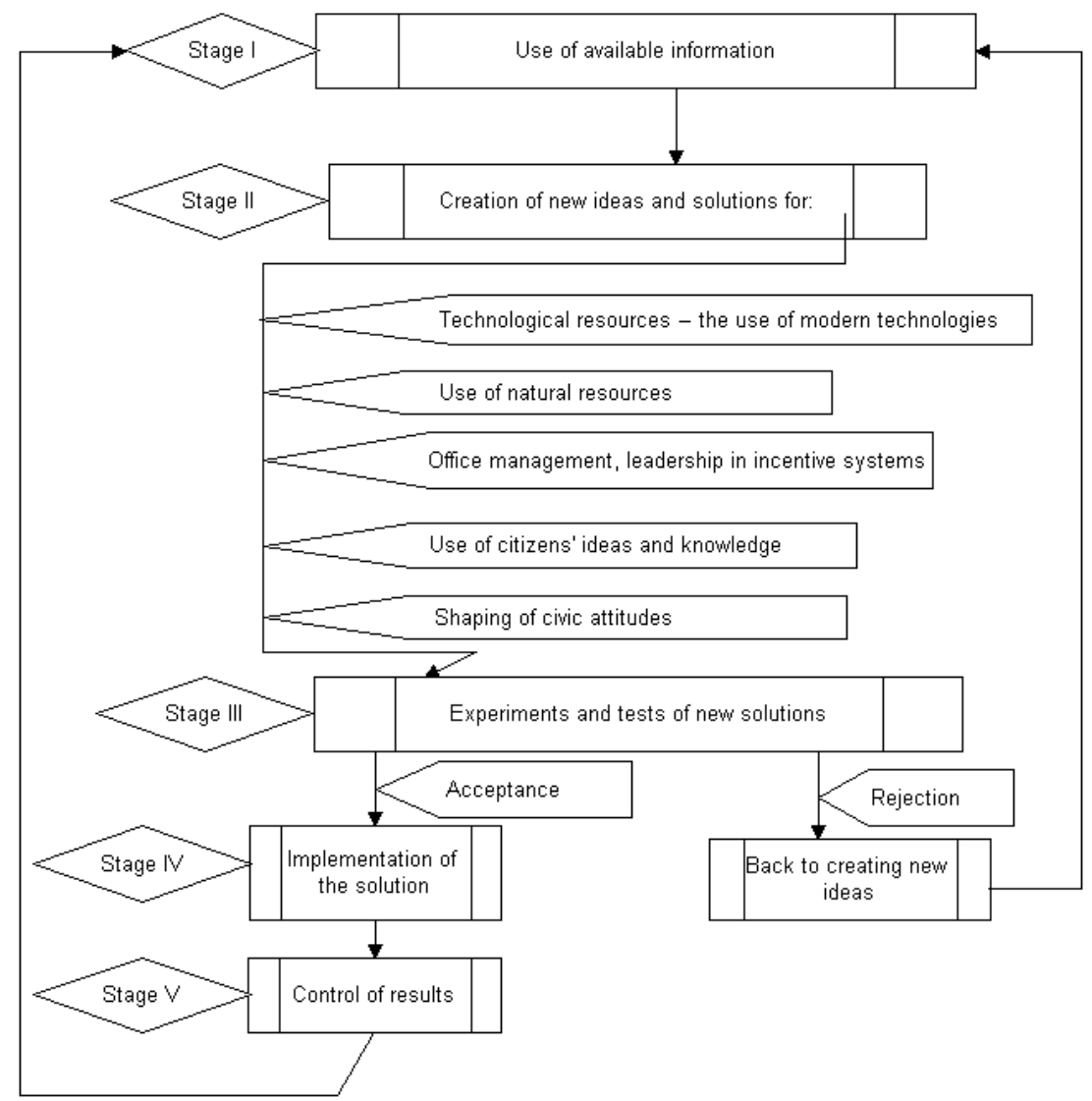

Figure 6. Model of local infrastructure creation (source: own work) 
According to Figure 6 showing a model of local infrastructure creation, the process has five stages. The first stage involves an analysis and assessment of information used as the basis for new ideas and solutions (in the second stage). The creation of new solutions should involve technological resources (the use of modern technologies in office or municipality management, purchase of new technologies, creation of new technologies); natural resources (the use of natural environment infrastructure); changes in incentive systems and attitudes of managers from management to leadership; the use of ideas, implementation of internal entrepreneurship; the shaping of civic attitudes, involvement of citizens in civic activity, events for children, youth, and seniors. The proposal of changes and new solutions is a transition point to the third stage, which involves experiments and tests of new solutions. The tests should be carried out on small samples. When a solution is rejected, the process starts anew at stage one. If a solution is accepted, the fourth stage starts, which implements the solution followed by the fifth stage, verification of results.

\section{Conclusions}

The paper set out to analyze the influence of innovation processes on the shaping of the local material, institutional, and intellectual infrastructure. The presented study suggests that innovation processes determine the shaping of the three types of infrastructure at the local level. The study shows that innovation processes in the investigated municipality exhibit average dynamics (90\% of public administration officers described the dynamics of innovation processes in the region as average and $10 \%$, as low). According to our observations, material infrastructure innovation is not being implemented. It is related to risk and implementation and use of new solutions, new technologies. The study shows that no new technologies are created or used at the local level. Financial issues are very often mentioned as reason for not adopting or developing innovation; our analysis revealed this is a persuasive argument but we have also identified a set of other determinants for innovation development and adoption.

We were able to observe and delineate innovation processes at the local level and can subscribe to the importance for competitiveness and quality of life. Innovation processes, in their different aspects, do influence the creation of material, intellectual and institutional infrastructures, while we showed that those infrastructures are essential to the fostering of innovation. The infrastructures, and their absences, also co-determine which kind of innovation processes take place and can place. As indicated earlier, this is also borne out by the literature. In the Polish cases, not that much innovation takes place at the local level, while many infrastructures are there. This indicates that the infrastructures do not automatically spur innovation. More research is needed for the Polish context, to identify which additional factors might be at play, but it is possible to find at least a partial explanation in the idea that innovation processes and infrastructures do not only engender path creation in economic development, but also new path dependencies. Certainly if we talk about governments, and the governance of innovation, we can see that the structuring of innovation processes, and the creation of infrastructure for innovation, attempts to create new pathways for innovation, yet paradoxically, each pathway also restricts innovation. If 'innovation' is conceived and structured in a uniform and institutionalized way, at the level of local government, this will 
inevitably create paths for doing the same things [resulting from patterns of infrastructures], or, doing relatively new things in the same way [as the innovation process itself does not transforms]. This then begs the question which patterns of infrastructures and innovative processes, in the Polish cases create the moderate innovation levels, competitiveness levels, while one can argue in many cases also a rather high quality of life.

The substitution of the traditional, bureaucratic management model in public administration with the New Public Administration (NPA) is an important factor contributing to the implementation of innovation processes and creation of the institutional infrastructure. The New Public Administration contributes to the successful implementation of innovation processes. This approach involves the abandonment of bureaucracy, changes in decisionmaking, increased focus on the quality of public services taking into account the needs and expectations of the citizen who is treated as a "customer of administration". Our observations yielded the conclusion that the implementation of the New Public Administration is not noticeable in the investigated municipality. The concept involves dispersed organizational structure, charismatic leadership, and decentralized power. According to persons working in the public administration, activities regarding the use of modern management methods, improvement of service quality, and orientation on the (inventiveness of the) local community are not taken in the municipality at all. The residents assessed the activities better. They believed the quality of the services to be partially changing and improving. Hence, it can be concluded that the Municipality of Myslenice needs the implementation of a new model of public administration and that the awareness of public administration officers regarding the significance of customer service should be improved. Actions taken to improve the quality of service or employ modern administration methods undoubtedly determine the implementation of innovation processes in a municipality.

As regards the use of innovation in the creation of the intellectual infrastructure, the flow of information among employees of the institution is restricted, communication is not open, and ideas of administration officers are not used in practice. The conclusion is that the Municipality of Myslenice does not take advantage of the concept of good governance. Hence, administration participation, open communication, and cohesive actions should be implemented. According to our observations, actions of social leaders are very noticeable, which supports the activities of public institutions and the formation of civil society in the investigated municipality. The conclusion is that social leaders are active in the municipality, which contributes to the formation of civil society.

An analysis of the collected information yielded a model of the process of creation of local infrastructure (Figure 6), which may be used by local governments to guide the local development.

Our Polish cases did clarify then that it is not always possible or necessary to drastically rethink infrastrucures for innovation, and innovation for infrastructure, but that it is often possible to identify blockages or obstacles for partial innovation or infrastructure development, innovations or infrastructures which all actors acknowledge could enhance local economic development and which could be influenced by the local community and government itself. This last point is seemingly simple but rather useful, as innovation is not always tied to a place, and as innovation cannot be entirely predicted or steered at the local level. Thus, 
what remains open is a new form of self-reflection at local level, in a more participatory manner, where actual local problems (hampering quality of life, economic development) are considered together with the local needs and possibilities for change. In such reflection, we know now that the triple infrastructure discussed above, and local innovation processes, shape each other over time.

\section{Funding}

This work was supported by the Ministry of Science and Higher Education of the Republic of Poland under Grant [DS 3371/KGPiAK/2018].

\section{Author contributions}

Magdalena Gorzelany - Dziadkowiec proposed concept, Julia Gorzelany and Magdalena Gorzelany - Dziadkowiec developed the concept of research and methodology, Julia Gorzelany and Magdalena Gorzelany - Dziadkowiec designed the research method, Julia Gorzelany and Magdalena Gorzelany - Dziadkowiec collected data, Julia Gorzelany and Magdalena Gorzelany - Dziadkowiec analysed the data and wrote the paper, Kristof van Assche, Julia Gorzelany and Magdalena Gorzelany - Dziadkowiec discussed the results, Józef Hernik and Gintaras Stauskis coordinated the work. All Authores analyzed the literature of the subject, Kristof van Assche, Gintaras Stauskis and Józef Hernik consulted the analysis. Tomasz Noszczyk edited the text. All authors have read and approved the final manuscript.

\section{Disclosure statement}

No potential conflict of interest was reported by the authors.

\section{References}

Adizes, I. (1988). Corporate lifecycles: how and why corporations grow and what to do about it. Englewood Cliffis: Prentice Hall.

Agovino, M., Aldieri, L., Garofalo, A., \& Vinci, C. P. (2017). Quality and quantity in the innovation process of firms: a statistical approach. Quality \& Quantity, 51(4), 1579-1591. https://doi.org/10.1007/s11135-016-0353-y

Agrawal, A., Galasso, A., \& Oettl, A. (2017). Roads and Innovation. Review of Economics and Statistics, 99(3), 417-434. https://doi.org/10.1162/REST_a_00619

Baula, O., Galaziuk, N., \& Zelinska, O. (2017). Conceptual framework for organizational and economic mechanism formation to increase the region competitiveness with the globalization of the world economic relations. Marketing and Management of Innovations, 2, 76-84. https://doi.org/10.21272/mmi.2017.2-07

Beeton, T. A., \& Galvin, K. A. (2017). Wood-based bioenergy in western Montana: the importance of understanding path dependence and local context for resilience. Ecology and Society, 22(2), 1-16. https://doi.org/10.5751/ES-09157-220209 
Bichai, F., Kajenthira Grindle, A., \& Murthy, S. L. (2018). Addressing barriers in the water-recycling innovation system to reach water security in arid countries. Journal of Cleaner Production, 171, 97-109. https://doi.org/10.1016/j.jclepro.2016.07.062

Biemans, W. G. (Ed.). (2018). Managing innovation within networks. London: Routledge. https://doi.org/10.4324/9780203701409

Bjørnskov, C., \& Méon, P.-G. (2013). Is trust the missing root of institutions, education, and development? Public Choice, 157(3-4), 641-669. https://doi.org/10.1007/s11127-013-0069-7

Bleicher, K. (1992). Das konzept integriertes management. Frankfurt/New York: Campus Verlag.

Bleicher, K. (1994). Normatives management: politik, verfassung und philosophie des unternehmens. Frankfurt: Campus-Verlag.

Buck, N. T., \& While, A. (2017). Competitive urbanism and the limits to smart city innovation: the UK Future Cities initiative. Urban Studies, 54(2), 501-519. https://doi.org/10.1177/0042098015597162

Churski, P., \& Dominiak, J. (2014). The impact of innovations on growth and stagnation regions in Poland. European Planning Studies, 22(6), 1143-1164. https://doi.org/10.1080/09654313.2013.767494

Coenen, L., Asheim, B., Bugge, M. M., \& Herstad, S. J. (2017). Advancing regional innovation systems: what does evolutionary economic geography bring to the policy table? Environment and Planning C: Politics and Space, 35(4), 600-620. https://doi.org/10.1177/0263774X16646583

Coleman, J. S. (1988). Social Capital in the creation of human capital. The American Journal of Sociology, 94, 95-120. https://doi.org/10.1086/228943

Cooke, P. N., Heidenreich, M., \& Braczyk, H. J. (2004). Regional innovation systems: the role of governance in a globalized world. Oxford UK: Routledge.

Davids, M., \& Frenken, K. (2018). Proximity, knowledge base and the innovation process: towards an integrated framework. Regional Studies, 52(1), 23-34.

https://doi.org/10.1080/00343404.2017.1287349

Diebolt, C., \& Hippe, R. (2019). The long-run impact of human capital on innovation and economic development in the regions of Europe. Applied Economics, 51(5), 542-563. https://doi.org/10.1080/00036846.2018.1495820

Djanibekov, U., Van Assche, K., Boezeman, D., Villamor, G. B., \& Djanibekov, N. (2018). A coevolutionary perspective on the adoption of sustainable land use practices: The case of afforestation on degraded croplands in Uzbekistan. Journal of Rural Studies, 59, 1-9. https://doi.org/10.1016/j.jrurstud.2018.01.007

Dominiak, J., \& Churski, P. (2012). The role of innovation in the formation of regions of development and those of economic stagnation in Poland. Studia Regionalne i Lokalne, 4(50), 54-77.

Dos Santos, F. T. (2007). The entrepreneur rural region: competitiveness, sustainability and innovation.

Esmaeilpoorarabi, N., Yigitcanlar, T., Guaralda, M., \& Kamruzzaman, M. (2018). Evaluating place quality in innovation districts: a Delphic hierarchy process approach. Land Use Policy, 76, 471-486. https://doi.org/10.1016/j.landusepol.2018.02.027

Fukuyama, F. (2001). Social capital, civil society and development. Third Word Quaterly, 22(1), 7-20. https://doi.org/10.1080/713701144

Garud, R., Kumaraswamy, A., \& Karnoe, P. (2010). Path dependence or path creation? Journal of Management Studies, 47(4), 760-774. https://doi.org/10.1111/j.1467-6486.2009.00914.x

Gawroński, K., \& Prus, B. (2015). Selected economic aspects of adopting a local spatial development plan exemplified by the commune of Tomice in Malopolskie province. Real Estate Management and Valuation, 23(4), 5-15. https://doi.org/10.1515/remav-2015-0031

Geels, F. W. (2002). Technological transitions as evolutionary reconfiguration processes: a multi-level perspective and a case-study. Research Policy, 31(8-9), 1257-1274.

https://doi.org/10.1016/S0048-7333(02)00062-8 
Greiner, L. E. (1972). Evolution and revolution as organizations grow. Harvard Business Review, 50(4), 37.

Głuszczuk, D. (2011). The essence of regional development and its determinants. Economics, 5(17), 68-80.

Hausner, J., Kudłacz, T., \& Szlachta, J. (1998). Identification of new regional development problems of Poland. Warsaw: Publishing house PWN.

Indus, K. (2018). The role and place of financial resources for the development of regions. Baltic Journal of Economic Studies, 4(3), 94-98. https://doi.org/10.30525/2256-0742/2018-4-3-94-98

Jedwab, R., Kerby, E., \& Moradi, A. (2017). History, path dependence and development: evidence from colonial railways, settlers and cities in Kenya. Economic Journal, 127(603), 1467-1494. https://doi.org/10.1111/ecoj.12347

Kelly, C., Ellis, G., \& Flannery, W. (2018). Exploring transition pathways as an alternative approach for the integrated management of Irish estuaries and coasts. In C. P. Heidkamp \& J. Morrissey (Eds.), Towards Coastal Resilience and Sustainability (pp. 57-78). London: Routledge.

Kooij, H. J., Van Assche, K., \& Lagendijk, A. (2014). Open Concepts as crystallization points and enablers of discursive configurations: the case of the innovation campus in the Netherlands. European Planning Studies, 22(1), 84-100. https://doi.org/10.1080/09654313.2012.731039

Kotnik, Z., \& Kovac, P. (2018). Development of public administration and governance in central and Eastern Europe: content analysis of the NISPAcee journal. Nispacee Journal of Public Administration and Policy, 11(1), 229-252. https://doi.org/10.2478/nispa-2018-0010

Kuhlmann, S., \& Ordóñez-Matamoros, G. (Eds.). (2017). Research handbook on innovation governance for emerging economies: towards better models. Edward Elgar Publishing. https://doi.org/10.4337/9781783471911

Latour, B. (Ed.). (1992). Aramis, or the love of technology. Harvard University Press.

Lee, S., \& Jung, K. (2018). The Role of community-led governance in innovation diffusion: the case of RFID Waste pricing system in the Republic of Korea. Sustainability, 10(9), 1-23. https://doi.org/10.3390/su10093125

Lewandowska, A., Stopa, M., \& Humenny, G. (2015). The European Union Structural funds and regional development. the perspective of small and medium enterprises in Eastern Poland. European Planning Studies, 23(4), 785-797. https://doi.org/10.1080/09654313.2014.970132

Madhavan, A., Sobczyk, A., \& Ang, A. (2018). What's in your benchmark? A factor analysis of major market indexes. Journal of Portfolio Management, 44(4), 46-59.

https://doi.org/10.3905/jpm.2018.44.4.046

Marynych, T. (2017). Empirical assessment of long-term aspects of sustainable regional development. Economic Annals-Xxi, 166(7-8), 86-90. https://doi.org/10.21003/ea.V166-17

Mason, S. G. (2010). Can community design build trust? A comparative study of design factors in Boise, Idaho neighborhoods. Cities, 27(6), 456-465. https://doi.org/10.1016/j.cities.2010.07.003

Ministry of Regional Development. (2008). The good governance concept - reflections to discussion. Warsaw. Retrieved from http://www.cnz.eurokreator.eu/dokumenty/Koncepcja_Good_Governance.pdf

Noboa, E., \& Upham, P. (2018). Energy policy and transdisciplinary transition management arenas in illiberal democracies: a conceptual framework. Energy Research and Social Science, 46, 114-124. https://doi.org/10.1016/j.erss.2018.07.014

Novalia, W., Brown, R. R., Rogers, B. C., \& Bos, J. J. (2018). A diagnostic framework of strategic agency: operationalising complex interrelationships of agency and institutions in the urban infrastructure sector. Environmental Science \& Policy, 83, 11-21. https://doi.org/10.1016/j.envsci.2018.02.004

Oyelaran-Oyeyinka, B. (Ed.). (2017). Learning to compete in African industry: institutions and technology in development. London/New York: Routledge. https://doi.org/10.4324/9781351154086 
Pajestka, J. (1975). Determinants of progress. Factors and interdependencies of socio-economic development. Warsaw: PWE.

Peiro-Palomino, J. (2016). Social Capital and economic growth in Europe: Nonlinear trends and heterogeneous regional effects. Oxford Bulletin of Economics and Statistics, 78(5), 717-751. https://doi.org/10.1111/obes.12131

Popov, E. V., Omonov, J. K., Naumov, I. V., \& Veretennikova, A. Y. (2018). Trends in the development of social innovation. Terra Economicus, 16(3), 35-59.

Purkus, A., Hagemann, N., Bedtke, N., \& Gawel, E. (2018). Towards a sustainable innovation system for the German wood-based bioeconomy: Implications for policy design. Journal of Cleaner Production, 172, 3955-3968. https://doi.org/10.1016/j.jclepro.2017.04.146

Quinn, R. E., \& Cameron, K. (1983). Organizational life cycles and shifting criteria of effectiveness some preliminary evidence. Management Science, 29(1), 33-51. https://doi.org/10.1287/mnsc.29.1.33

Raszkowski, A., \& Bartniczak, B. (2018). Towards sustainable regional development: economy, society, environment, good governance based on the example of Polish regions. Transformations in Business \& Economics, 17(2), 225-245.

Romao, J., \& Neuts, B. (2017). Territorial capital, smart tourism specialization and sustainable regional development: Experiences from Europe. Habitat International, 68, 64-74. https://doi.org/10.1016/j.habitatint.2017.04.006

Rowe, J. E. (2019). Regional development in Australia: Being regional. New Zealand Geographer, 75(1), 45-46. https://doi.org/10.1111/nzg.12211

Sanchez-Carreira, M. D., Penate-Valentin, M. C., \& Varela-Vazquez, P. (2017). Demand policies in the innovation process: fundamentals and instruments. Revista De Investigaciones Politicas Y Sociologicas, 16(2), 229-248. https://doi.org/10.15304/rips.16.2.4162

Saubanov, K., Nikolaev, M., \& Beliakin, A. (2017). Innovation risks in the process of the region's competitiveness management. National Academy of Managerial Staff of Culture and Arts Herald, 2, 134-139.

Schramm, E., Kerber, H., Trapp, J. H., Zimmermann, M., \& Winker, M. (2018). Novel urban water systems in Germany: governance structures to encourage transformation. Urban Water Journal, 15(6), 534-543. https://doi.org/10.1080/1573062X.2017.1293694

Schumpeter, J. A. (1934). Theory of Economic development: an inquiry into profits, capital, credit, interest, and the business cycle. London: Harvard University Press.

Sierocińska, K. (2011). Social capital: definitions, measurement, and types. Economic Studies, 1(68), 69-86.

Sunina, L., \& Rivza, B. (2016). The quintuple Helix model: way of regional development cantres in Latvia to smart public administration. Research for Rural Development 2016, 2, 135-142.

Szreder, M. (2004). Metody i techniki sondażowych badań opinii. Warsaw: Polish Economic Publishing House (in Polish).

Van Assche, K., Beunen, R., \& Duineveld, M. (2013). Evolutionary governance theory: an introduction. In K. Van Assche, R. Beunen, \& M. Duineveld (Eds.), Evolutionary governance theory (pp. 3-6). Heidelberg: Springer. https://doi.org/10.1007/978-3-319-00984-1_1

Van Assche, K., Beunen, R., Duineveld, M., \& Gruezmacher, M. (2017). Power/knowledge and natural resource management: Foucaultian foundations in the analysis of adaptive governance. Journal of Environmental Policy \& Planning, 19(3), 308-322. https://doi.org/10.1080/1523908X.2017.1338560

Van Assche, K., Deacon, L., Gruezmacher, M., Summers, R. J., Lavoie, S., Jones, K. E., Granzow, M., Hallstrom, L., \& Parkings, J. (Eds.). (2017). Boom \& Bust. Local strategy for big events. A community survival guide to turbulent times. Groningen/Edmonton: InPlanning and University of Alberta, Faculty of Extension. 
Van Assche, K., \& Hornidge, A. K. (Eds.). (2015). Rural development. Knowledge and expertise in governance. Wageningen: Wageningen Academic. https://doi.org/10.3920/978-90-8686-812-4

Van der Voet, J. (2017). Enhancing Public Innovation by Transforming Public Governance. Journal of Public Administration Research and Theory, 27(4), 713-715. https://doi.org/10.1093/jopart/mux011

Vergragt, P. J. (2017). Transition management for sustainable personal mobility: the case of hydrogen fuel cells. In P. Nieuwenhuis, P. J. Vergragt, \& P. Wells (Eds.), The business of sustainable mobility (pp. 19-34). London: Routledge. https://doi.org/10.4324/9781351280969-2

Wu, J., Zhuo, S. H., \& Wu, Z. F. (2017). National innovation system, social entrepreneurship, and rural economic growth in China. Technological Forecasting and Social Change, 121, 238-250. https://doi.org/10.1016/j.techfore.2016.10.014

Yu, K. P. (2018). Governance and good governance: a new framework for political analysis. Fudan Journal of the Humanities and Social Sciences, 11(1), 1-8. https://doi.org/10.1007/s40647-017-0197-4

Zhan, C. J., de Jong, M., \& de Bruijn, H. (2017). Path Dependence in financing urban infrastructure development in China: 1949-2016. Journal of Urban Technology, 24(4), 73-93.

https://doi.org/10.1080/10630732.2017.1334862 